\title{
Quality of 'Fuji Suprema' apples influenced by long-term annual addition of phosphorus to the soil
}

\section{Jaqueline Muniz Gerber ${ }^{*}$ Gilberto Nava ${ }^{2}$ Paulo Roberto Ernani $^{1}$ Marlise Nara Ciotta $^{3}$ Cassandro Vidal Talamini do Amarante ${ }^{1}$ Milton César Coldebella ${ }^{1}$}

${ }^{1}$ Universidade do Estado de Santa Catarina (UDESC), 88.520-000, Lages, SC, Brasil. E-mail: gerber.jaqueline@gmail.com. " ${ }^{*}$ orresponding author. ${ }^{2}$ Empresa Brasileira de Pesquisa Agropecuária (EMBRAPA), Clima Temperado, Pelotas, RS, Brasil.

${ }^{3}$ Empresa de Pesquisa Agropecuária e Extensão Rural de Santa Catarina (EPAGRI), São Joaquim, SC, Brasil.

\begin{abstract}
Fertilization of apple orchards with phosphorus $(P)$ has received less attention than with nitrogen and potassium. In Brazil, the information about apple response to soil P addition is meager. The objective of this study was to evaluate the long-term effect of annual soil $P$ addition on quality and mineral composition of apple fruits. The experiment started in 2010, in a commercial orchard located in the São Joaquim, Southern of Brazil. The orchard consisted of 'Fuji Suprema', planted in high-density on a Haplumbrept soil. Treatments consisted of $0,40,80,120$ and $160 \mathrm{~kg} \mathrm{ha-1} P_{2} O_{5}$ applied annually starting in 2010 broadcast over the soil surface along the tree row. Evaluations were performed from 2012/2013 through 2014/2015 growing seasons. We harvested three samples from each experimental unit. One sample was cold stored in a controlled atmosphere chamber for six months; the others were immediately evaluated for firmness, total soluble solids, titratable acidity (TA), skin color, and the concentrations of $N, P, K, C a$ and $M g$ in the fruit flesh. Application of $P$ to the soil affected only flesh firmness at harvest and TA after six months of storage in the 2012/2013 season, as well as firmness after six months of storage in the 2013/2014 season. In the 2014/2015 season, the addition of P reduced fruit color but only at harvest. Addition of P to the soil affected the levels of $P$ in the fruit in the 2012/2013 season, as well as $N$ and the N/Ca ratio of fruit in the 2014/2015 season. Overall, attributes related to fruit quality of cultivar Fuji Suprema were slightly affected by long-term annual addition of $P$ to the soil.

Key words: Malus $x$ domestica Borkh, fruit quality, phosphate fertilization.
\end{abstract}

Qualidade de frutos de maçã 'Fuji Suprema' influenciada pela adição anual de longo prazo de fósforo ao solo

RESUMO: A adubação com fósforo (P) em pomares de maçã tem recebido menos atenção que adubações com nitrogênio e potássio. No Brasil, as informações sobre a resposta da macieira a adição de P ao solo é escassa. O objetivo deste estudo foi avaliar o efeito a longo prazo da adição anual de $P$ ao solo na qualidade e composição mineral de maçãs. O experimento iniciou em 2010, num pomar comercial localizado no municipio de São Joaquim, Sul do Brasil, com a cultivar 'Fuji Suprema', instalado em alta densidade (aproximadamente 2.000 plantas $\mathrm{ha}^{-1}$ ) em um solo Haplumbrept. Os tratamentos consistiram de 0,40,80, 120 e $160 \mathrm{~kg} \mathrm{ha}^{-1} \mathrm{P}_{2} \mathrm{O}_{5}$ aplicados anualmente a partir de 2010 , na superficie do solo ao longo da fileira das árvores. As avaliações foram realizadas nas estações de crescimento de 2012/2013 até $2014 / 2015$. Três amostras de 10 frutos de cada unidade experimental foram colhidas. Uma amostra foi armazenada em uma câmara fria de atmosfera controlada por seis meses; os outros foram imediatamente avaliados quanto à firmeza, sólidos solúveis totais, acidez titulável (AT), cor da epiderme e as concentrações de N, P, K, Ca e Mg na polpa dos frutos. A aplicação de P ao solo afetou apenas a firmeza de polpa na colheita e AT após seis meses de armazenamento na safra 2012/2013, bem como a firmeza após seis meses de armazenamento na safra 2013/2014. Na safra 2014/2015, a adição de P reduziu a cor dos frutos, mas apenas na colheita. A adição de $P$ ao solo afetou os niveis de P nos frutos da safra 2012/2013, bem como $N$ e a relação $N$ / Ca de frutas na safra 2014/2015. Em geral, os atributos relacionados à qualidade dos frutos da cultivar Fuji Suprema foram ligeiramente afetados pela adição anual prolongada de $P$ ao solo.

Palavras-chave: Malus x domestica Borkh, qualidade de fruto, adubação fosfatada.

\section{INTRODUCTION}

Yield and quality of apple fruit are affected by climatic conditions and by orchard management practices including pruning, thinning, control of weeds, insects and diseases, and nutrient supply. In terms of plant nutrition, fertilization of apple orchards with phosphates has received much less attention than fertilization involving nitrogen $(\mathrm{N})$ and potassium $(\mathrm{K})$. This is mainly because $\mathrm{P}$ addition to the soil in established orchards normally has low or no effect on apple yield (NAVA et al., 2017). In addition to a low demand for $\mathrm{P}$, the lack of apple yield response to soil $\mathrm{P}$ application is due to the release of reasonable amounts of organic P from the organic matter decomposition, the contribution of arbuscular mycorrhizae fungi, which increase the capacity of roots to take up P, and due to mild winters in subtropical regions, which allows roots to uptake $\mathrm{P}$ over the entire year and store it for periods of high demand. 
There are few studies around the world evaluating the effect of $\mathrm{P}$ addition to the soil on apple yield. On Canadian soils, fertigation with $\mathrm{P}$ at bloom at a rate of $20 \mathrm{~g}$ P per tree increased the average apple yield by $20 \%$ for 'Fuji', 'Gala', 'Ambrosia', 'Silken' and 'Cameo' during the first five fruiting seasons (NEILSEN et al., 2008) complete block, split-plot experimental design with six replicates was established and maintained annually for the first five fruiting seasons 1999 to 2003. In Poland, WOJCIK \& WOJCIK (2007) applied phosphate and phosphate plus lime to a P deficient 'Jonagold' orchard and reported no increases on fruit yield due to soil $\mathrm{P}$ application when the soil pH was adequate. In Brazil, the only paper in the literature reporting the effect of $\mathrm{P}$ addition to the soil on apple orchards showed no increases on fruit yield (NAVA et al., 2017).

Conversely, the content of $\mathrm{P}$ in the apple fruit affects many physical and chemical attributes related to fruit quality and conservation such as reductions in incidence of water core at harvest, increased resistance to browning, elevated antioxidant content of fruit (NEILSEN et al., 2008), and increased fruit appearance and storability (WOJCIK \& WOJCIK, 2007). In addition, spraying apple trees with $\mathrm{P}$ increased the contents of this nutrient in the fruit and decreased the loss of flesh firmness (WEBSTER \& LIDSTER, 1986) and the susceptibility caused by low temperatures (JOHNSON \& YOGORATNAM, 1978). Apples containing less than $100 \mathrm{mg} \mathrm{kg}^{-1} \mathrm{P}$ have high risks of developing physiological disorders during and after storage (AMARANTE et al., 2012). According to NEILSEN et al. (2008) best apple performance was associated with leaf $\mathrm{P}$ concentration above $2.2 \mathrm{mg} /$ $\mathrm{g}^{-1}$ dry weight and fruit $\mathrm{P}$ concentration between 100 and $120 \mathrm{mg} \mathrm{kg}^{-1}$ dry weight. Thus, low availability of $\mathrm{P}$ in the soil results in small uptake of this nutrient by plants, which may negatively affect fruit quality.

The region of São Joaquim offers the best climatic conditions for growing apples in Brazil. Most soils of this region are; however, shallow and stony (SOUZA et al., 2013). In addition, they naturally have low $\mathrm{P}$ availability and high adsorption capacity for this nutrient (ERNANI et al., 1996). Since they also have high organic matter content, reasonable amounts of $\mathrm{P}$ become plant available from the organic matter decomposition over time. Brazilian apple growers apply large amounts of $\mathrm{P}$ fertilizers before orchard installation (CQFS-RS/SC, 2016) to promote tree growth, but are uncertain on the best fertilization practices on the following years, during fruit production. In order to avoid any possibility of
P deficiency, some growers apply large amounts of phosphates annually, resulting in a build up in the soil $\mathrm{P}$ pool with both risks of $\mathrm{P}$ contamination (SCHMITT et al., 2017) and unnecessary expenses.

The present study was carried out to clarify the effect of soil $\mathrm{P}$ addition on fruit quality in a Brazilian apple orchard planted over rocky shallow soils in the São Joaquim region.

\section{MATERIALS AND METHODS}

The experiment was conducted in a commercial orchard located in the municipality of São Joaquim, Brazil (28 17 ' 25' S, 49 $56^{\circ}$ ' 56" Waltitude of $1200 \mathrm{~m}$ ) in an Haplumbrept soil containing $48 \mathrm{~g} \mathrm{dm}^{-3}$ organic matter and $470 \mathrm{~g} \mathrm{dm}^{-3}$ clay. The region has a humid mesothermal climate $(\mathrm{Cfb}$ according to the Köppen classification) with mild summers, cold winters, and annual average temperature and pluvial precipitation of $13^{\circ} \mathrm{C}$ and $1,600 \mathrm{~mm}$ respectively.

The orchard was planted in June 2004 with 'Fuji Suprema' trees grafted on Marubakaido/M9 rootstock, spaced $4.2 \mathrm{~m} \times 1.2 \mathrm{~m}$. Two months before planting, dolomitic limestone and $\mathrm{P}$ and $\mathrm{K}$ fertilizers were broadcasted and mixed with soil to a depth of $0-40 \mathrm{~cm}$, at rates recommended by the Santa Catarina State liming and fertilization manual. Treatments consisted of $0,40,80120$ and $160 \mathrm{~kg} \mathrm{ha}^{-1} \mathrm{P}_{2} \mathrm{O}_{5}$ added annually since 2010 from triple superphosphate and broadcasted over the soil surface in a 2.2-m-wide strip centered on the tree row. Treatments were replicated five times in a complete randomized block design, and each experimental unit consisted of seven plants along the row, where only the central five trees were used for evaluations. Before treatments application the soil had $\mathrm{pH}=6.4, \mathrm{P}$ (Mehlich-1) $4.3 \mathrm{mg} \mathrm{dm}^{-3}$, $\mathrm{K} 0.25 \mathrm{cmol}_{\mathrm{c}} \mathrm{dm}^{-3}, \mathrm{Ca} 11.5 \mathrm{cmol}_{\mathrm{c}} \mathrm{dm}^{-3}, \mathrm{Mg} 4.3 \mathrm{cmol}_{\mathrm{c}}$ $\mathrm{dm}^{-3}$. Evaluations were performed from 2012/2013 to 2014/2015 growing seasons.

The experimental area received all management practices used in the commercial orchard, including application of herbicide (glyphosate; roundup), insecticides, and fungicides, winter and summer pruning, hand thinning, and mineral oil plus hydrogen cyanamide to stimulate bud break.

Triplicate samples of 10 fruit each were collected at harvest from any experimental unit. One sample was cold stored for six months in a regular air chamber (at $0.5^{\circ} \mathrm{C}$ and $90 \% \mathrm{RH}$ ) before evaluations; the other two samples were used for laboratory evaluations immediately following harvest. On all fruit samples we determined firmness, soluble solids concentration, titratable acidity, skin 
color, and concentrations of $\mathrm{N}, \mathrm{P}, \mathrm{K}, \mathrm{Ca}$ and $\mathrm{Mg}$ in the fruit flesh. Fruit firmness determinations were taken on the opposite cheeks of each fruit, midway between the stem-end and calyx-end, after peel removing, using an electronic penetrometer with $11 \mathrm{~mm}$ diameter plunger on the cut surfaces. Soluble solids concentration, $\mathrm{SSC},\left({ }^{\circ} \mathrm{Brix}\right)$, were determined in a small sample of fruit juice using a hand held digital refractometer containing a temperature compensation capability. Titratable acidity (TA), expressed as \% malic acid, was determined in a $10 \mathrm{~mL}$ sample juice diluted into $20 \mathrm{~mL}$ of distilled water following titration with $0.1 \mathrm{~mol} \mathrm{~L}^{-1} \mathrm{NaOH}$ to a $\mathrm{pH}$ end point of 8.1, using automatic titrator.

The hue $\left(h^{\circ}\right)$ angle and lightness $(L)$ of fruit skin were measured using a colorimeter (Minolta CR 400, Japan). Readings were performed midway between the stem-end and calyx-end on the reddest portion of the fruit. The $h^{\circ}$ represents the intensity of the red color and defines the basic color, where $0^{\circ}=$ red, $90^{\circ}=$ yellow and $180^{\circ}=$ green, which means that as the $h^{\circ}$ angle decreases the red color of the skin increases. The ' $L$ ' value represents the color brightness, which varies from $0^{\circ}=$ black to $100^{\circ}=$ white.

To evaluate the mineral composition, each fruit was cut longitudinally twice to produce two seedless, wedge-shaped segments, which constituted the fruit sample. Slices, that were blended and homogenized with a RI 6720 multiprocessor and a
Braun Multiquick MR40 mixer, respectively. For the determination of $\mathrm{Ca}, \mathrm{Mg}$ and $\mathrm{K}, 5.0 \mathrm{~g}$ of the slurry were incinerated in an oven at $630^{\circ} \mathrm{C}$ for five hours. Then, the ashes were solubilized by adding $15 \mathrm{~mL}$ of $1.8 \mathrm{~mol} \mathrm{~L}^{-1} \mathrm{HCl}$.

Calcium and $\mathrm{Mg}$ were determined by atomic absorption spectroscopy (Aanalyst 200 PerkinElmer); K was quantified by flame emission photometer (Digimed DM-61). For the quantification of $\mathrm{N}$ and $\mathrm{P}, 2.0 \mathrm{~g}$ of fruit flesh were wet-digested with $5 \mathrm{~mL} \mathrm{H}_{2} \mathrm{O}_{2}+3 \mathrm{~mL} \mathrm{H}_{2} \mathrm{SO}_{4}$ at $350^{\circ} \mathrm{C}$ for three hours. Then, $\mathrm{N}$ was determined by steam distillation using a semi-micro-Kjedahl equipment (TEDESCO et. al., 1995); P was quantified by colorimetry using method Murphy \& Riley.

Data were submitted to analysis of variance (ANOVA). When there was a significance for $\mathrm{P}$ rates, polynomial regression equations $(\mathrm{P}<0.05)$ were adjusted, using the SAS software.

\section{RESULTS AND DISCUSSION}

Long-term addition of $\mathrm{P}$ to the soil did not affect the titratable acidity (TA) nor the soluble solids concentration (SSC) in samples evaluated at harvest (Table 1). Averaged across $\mathrm{P}$ rates and years, malic acid was $0.35 \%$ while SSC was $11.3^{\circ}$ Brix. These values are in the range considered adequate for 'Fuji' apples, which vary from 0.2 to $0.4 \%$ of malic acid and

Table 1 - Effect of the rate of soil applied P on attributes related to fruit quality of 'Fuji Suprema' measured at harvest.

\begin{tabular}{|c|c|c|c|c|c|}
\hline \multirow[t]{2}{*}{$\begin{array}{l}\text { Rates of } \mathrm{P}_{2} \mathrm{O}_{5} \\
\left(\mathrm{~kg} \mathrm{ha}^{-1}\right)\end{array}$} & \multirow[t]{2}{*}{$\begin{array}{l}\text { Titratable acidity } \\
\text { (\% malic acid) }\end{array}$} & \multirow[t]{2}{*}{$\begin{array}{c}\text { Soluble solids } \\
\left.\text { concentration ( }{ }^{\circ} \text { Brix }\right)\end{array}$} & \multirow[t]{2}{*}{ Flesh firmness (Newton) } & \multicolumn{2}{|c|}{ Fruit skin color at the reddest side } \\
\hline & & & & $\mathrm{L}^{(1)}$ & $h^{\circ(2)}$ \\
\hline \multicolumn{6}{|c|}{ - } \\
\hline 0 & 0.36 & 11.5 & 76.3 & 40.2 & 26.9 \\
\hline 40 & 0.36 & 11.8 & 79.0 & 39.9 & 25.6 \\
\hline 80 & 0.38 & 11.4 & 78.2 & 39.1 & 28.8 \\
\hline 120 & 0.27 & 10.5 & 78.7 & 38.8 & 27.6 \\
\hline 160 & 0.37 & 10.4 & 80.2 & 40.0 & 28.5 \\
\hline Linear & ns & ns & $*$ & Ns & ns \\
\hline Quadratic & ns & ns & ns & Ns & ns \\
\hline \multicolumn{6}{|c|}{--- } \\
\hline 0 & 0.36 & 11.4 & 70.7 & 37.6 & 28.8 \\
\hline 40 & 0.37 & 11.8 & 69.7 & 37.4 & 29.3 \\
\hline 80 & 0.34 & 11.6 & 71.4 & 38.6 & 31.3 \\
\hline 120 & 0.35 & 11.3 & 70.9 & 37.9 & 30.3 \\
\hline 160 & 0.36 & 11.4 & 71.1 & 39.8 & 32.4 \\
\hline Linear & $\mathrm{ns}$ & ns & ns & $*$ & ${ }^{* *}$ \\
\hline Quadratic & ns & $\mathrm{ns}$ & ns & Ns & $\mathrm{ns}$ \\
\hline
\end{tabular}

ns, ${ }^{*},{ }^{* *}$, not significant: effect of $\mathrm{P}$ rate not significant or significant at 5 and $1 \%$ probability levels, respectively.

(1) 'Lightness' (L).

(2)'Hue' $\left(h^{\circ}\right)$ represents the intensity of the red color and defines the basic color. 
from 10 to $12^{\circ}$ Brix (TREPTOW et al., 1995). Flesh firmness; however, increased linearly with increase of $P$ rate applied, but only in the 2012/2013 growing season (Table 1). The mean value for firmness was 75 Newton, which is considered high for 'Fuji' (HUNSCHE et al., 2003). According to ARGENTA et al. (1995) 'Fuji' apples should have firmness at harvest higher than 71 Newton for long term storage. Firmness is the fruit trait normally most associated with apple conservation.

For parameters related to fruit color determined at harvest, the $h^{\circ}$ angle and $L$ at the side exposed to the sun showed a decrease on the skin red color with increases on $\mathrm{P}$ addition to the soil, but only on the last growing season (2014/2015). The treatment that received the highest annual $\mathrm{P}$ rate (160kg ha-1 $\mathrm{P}_{2} \mathrm{O}_{5}$ ) had less color than the control, which did not receive $\mathrm{P}$ (Table 1). This result in less anthocyanins, pigment associated with the red color, accumulation in the fruit skin (AMARANTE et al., 2007). This effect; however, did not happen in the other seasons regardless of the time of evaluation, at harvest of after cold storage. NEILSEN et al. (2008) evaluated the effect of P addition to the soil via fertigation in Canadian orchards and did not find any influence of this nutrient on soluble solids, total acidity, flesh firmness and fruit color of 'Ambrosia', 'Cameo', 'Fuji', 'Gala' and 'Silken'.

On determinations performed six months after fruit stored at $0.5^{\circ} \mathrm{C}$ and $90 \% \mathrm{RH}$, soluble solids concentration were not affected by long-term annual addition of $\mathrm{P}$ to the soil; total acidity; however, increased fP rate, but only for the 2012/2013 growing season (Table 2). The opposite occurred with flesh firmness on fruit from the 2013/2014 growing season, which decreased with increased $\mathrm{P}$ application rate. No attribute related to fruit skin color was affected by addition of $\mathrm{P}$ to the soil (Table 2), demonstrating that differences reported at harvest on the 2014/2015 growing season may not persist during storage.

The content of $\mathrm{P}$ in the fruits increased linearly with increased $\mathrm{P}$ application rate, but only in

Table 2 - Effect of the rate of soil applied P on attributes related to fruit quality of 'Fuji Suprema' measured after six months of cold storage.

\begin{tabular}{|c|c|c|c|c|c|}
\hline \multirow[t]{2}{*}{$\begin{array}{l}\text { Rates of } \mathrm{P}_{2} \mathrm{O}_{5} \\
\left(\mathrm{~kg} \mathrm{ha}^{-1}\right)\end{array}$} & \multirow[t]{2}{*}{$\begin{array}{l}\text { Titratable acidity } \\
(\% \text { malic acid })\end{array}$} & \multirow[t]{2}{*}{$\begin{array}{l}\text { Soluble solids concentration } \\
\left({ }^{\circ} \text { Brix }\right)\end{array}$} & \multirow[t]{2}{*}{ Flesh firmness (Newton) } & \multicolumn{2}{|c|}{$\begin{array}{l}\text { Fruit skin color at the } \\
\text { reddest side }\end{array}$} \\
\hline & & & & $L^{(1)}$ & $h^{\circ(2)}$ \\
\hline & & Growing season 2012/2013- & & ----- & ------ \\
\hline 0 & 0.30 & 13.7 & 76.2 & 38.4 & 26.7 \\
\hline 40 & 0.31 & 13.7 & 76.1 & 37.7 & 26.7 \\
\hline 80 & 0.34 & 13.8 & 77.3 & 39.0 & 28.7 \\
\hline 120 & 0.32 & 13.6 & 76.0 & 38.5 & 27.4 \\
\hline 160 & 0.39 & 13.7 & 76.6 & 38.5 & 28.2 \\
\hline Linear & & ns & ns & Ns & ns \\
\hline Quadratic & ns & ns & ns & Ns & ns \\
\hline - & - & ----Growing season 2013/20 & 4--------------------------------- & 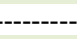 & \\
\hline 0 & 0.32 & 11.9 & 69.7 & 39.3 & 39.9 \\
\hline 40 & 0.29 & 10.9 & 68.2 & 41.5 & 42.5 \\
\hline 80 & 0.30 & 13.0 & 67.9 & 41.1 & 40.9 \\
\hline 120 & 0.31 & 11.3 & 68.0 & 42.0 & 45.7 \\
\hline 160 & 0.29 & 10.5 & 69.1 & 40.4 & 41.3 \\
\hline Linear & ns & ns & ns & Ns & ns \\
\hline Quadratic & ns & ns & & Ns & ns \\
\hline --------- & & -Growing season 2014/2015 & ------ & & \\
\hline 0 & 0.20 & 11.3 & 65.7 & 39.7 & 33.8 \\
\hline 40 & 0.21 & 12.0 & 65.5 & 38.0 & 30.6 \\
\hline 80 & 0.22 & 11.8 & 66.4 & 38.6 & 31.5 \\
\hline 120 & 0.21 & 11.7 & 65.6 & 38.8 & 31.5 \\
\hline 160 & 0.23 & 11.7 & 67.5 & 39.2 & 33.1 \\
\hline Linear & ns & ns & ns & Ns & ns \\
\hline Quadratic & ns & ns & ns & Ns & ns \\
\hline
\end{tabular}

$\mathrm{ns},{ }^{*},{ }^{* *}$, not significant: effect of $\mathrm{P}$ rate not significant or significant at 5 and $1 \%$ probability levels, respectively.

(1) 'Lightness' (L). 0 = black, $100=$ white.

${ }^{(2)}$ 'Hue' $\left(h^{\circ}\right)$ represents the intensity of the red color and defines the basic color. 
the first growing season $(2012 / 2013)$ (Table 3), which increased from $121 \mathrm{mg} \mathrm{kg}^{-1}$ for the control (with no $\mathrm{P}$ addition) to $162 \mathrm{mg} \mathrm{kg}^{-1}$ for the treatment that received the highest $\mathrm{P}$ rate $\left(160 \mathrm{~kg} \mathrm{ha}^{-1} \mathrm{P}_{2} \mathrm{O}_{5}\right)$. Deficient $\mathrm{P}$ in apple fruit can cause development of physiological disorders (AMARANTE et al., 2012). NEILSEN et al. (2008) reported that 'Fuji' and 'Silken' fruit with less than $100 \mathrm{mg} \mathrm{kg}^{-1} \mathrm{P}$ had more water core and lower storage life relatively to fruit with higher $\mathrm{P}$ contents. In our study, fruit from all treatments, including the control, always had $\mathrm{P}$ concentrations above $100 \mathrm{mg}$ $\mathrm{kg}^{-1}$, which is adequate for long-term storage. This high $\mathrm{P}$ uptake in the control can possibly be explained by the amount of $\mathrm{P}$ released from the organic matter decomposition (NAVA et al., 2017) and by the contribution of mycorrhizae (GASTOL et al., 2016).

The concentration of $\mathrm{N}$ in the fruit decreased linearly with increased $\mathrm{P}$ rate applied to the soil, but only for the 2014/2015 growing season (Table 3). Nitrogen changed from $494 \mathrm{mg}$ $\mathrm{kg}^{-1}$ in the control to $374 \mathrm{mg} \mathrm{kg}^{-1}$ for the highest $\mathrm{P}$ rate $\left(160 \mathrm{~kg} \mathrm{ha}^{-1} \mathrm{P}_{2} \mathrm{O}_{5}\right)$, which are within the normal concentration range for apple fruit to avoid development of physiological disorders, which are often found with apples containing more than $500 \mathrm{mg} \mathrm{kg}^{-1} \mathrm{~N}$ (AMARANTE et al., 2012). Apples with high $\mathrm{N}$ concentration normally have reduced storage life and are susceptible to incidence of rots and other physiological disorders (NEILSEN \& NEILSEN, 2009).

Concentrations of $\mathrm{Ca}, \mathrm{Mg}$ and $\mathrm{K}$ in the fruits were not affected by long-term $\mathrm{P}$ addition to the soil in any growing season (Table 3 ). Calcium is often the nutrient most associated with fruit quality and storage life since one of its physiological functions is to maintain the integrity of the cell wall. When Ca values in apple fruits are lower than $40 \mathrm{mg} \mathrm{kg}^{-1}$ (AMARANTE et al., 2012), cell membranes lose permeability causing disintegration and cell death (AMARANTE et al., 2006; BRACKMANN et al., 2010). Excess $\mathrm{Mg}$ and $\mathrm{K}$ in the fruit can exacerbate the negative effect caused by low $\mathrm{Ca}$ values. The adequate range for these two nutrients in apples fruits are respectively below 1,000 and $40 \mathrm{mg} \mathrm{kg}^{-1}$ (AMARANTE et al., 2012).

Annual addition of $\mathrm{P}$ to the soil decreased the $\mathrm{N} / \mathrm{Ca}$ ratio in the fruits only in the 2014/2015 growing season; the ratios of $\mathrm{K} / \mathrm{Ca}$ and $(\mathrm{K}+\mathrm{Mg}) /$

Table 3 - Effect of the rate of soil applied P on mineral composition of 'Fuji Suprema' fruits measured at harvest.

\begin{tabular}{|c|c|c|c|c|c|c|c|c|}
\hline $\begin{array}{l}\text { Rates of } \mathrm{P}_{2} \mathrm{O}_{5} \\
\left(\mathrm{~kg} \mathrm{ha}^{-1}\right)\end{array}$ & $\mathrm{P}$ & $\mathrm{N}$ & $\mathrm{K}$ & $\mathrm{Ca}$ & $\mathrm{Mg}$ & $\mathrm{N} / \mathrm{Ca}$ & $\mathrm{K} / \mathrm{Ca}$ & $(\mathrm{K}+\mathrm{Mg}) / \mathrm{Ca}$ \\
\hline & \multicolumn{8}{|c|}{$\mathrm{mg} \mathrm{kg}^{-1}$} \\
\hline \\
\hline 0 & 121 & 381 & 913 & 106 & 68 & 3.84 & 8.72 & 9.40 \\
\hline 40 & 127 & 475 & 920 & 88 & 66 & 7.44 & 15.10 & 16.1 \\
\hline 80 & 149 & 377 & 953 & 106 & 70 & 3.66 & 9.50 & 10.2 \\
\hline 120 & 137 & 380 & 855 & 104 & 69 & 3.88 & 8.64 & 9.32 \\
\hline 160 & 162 & 459 & 860 & 88 & 63 & 5.24 & 9.82 & 10.5 \\
\hline Linear & $*$ & ns & ns & ns & ns & ns & $\mathrm{ns}$ & $\mathrm{ns}$ \\
\hline Quadratic & ns & ns & ns & ns & ns & ns & ns & ns \\
\hline \multicolumn{9}{|c|}{ - Growing season 2013/2014--- } \\
\hline 0 & 118 & 440 & 954 & 119 & 72 & 3.94 & 8.40 & 9.02 \\
\hline 40 & 122 & 405 & 878 & 126 & 72 & 3.18 & 7.03 & 7.58 \\
\hline 80 & 113 & 366 & 839 & 127 & 61 & 2.94 & 7.12 & 7.66 \\
\hline 120 & 112 & 382 & 860 & 127 & 71 & 3.05 & 6.83 & 7.38 \\
\hline 160 & 105 & 391 & 773 & 141 & 66 & 3.30 & 6.07 & 6.57 \\
\hline Linear & ns & ns & ns & ns & ns & ns & ns & ns \\
\hline Quadratic & $\mathrm{ns}$ & ns & ns & ns & ns & ns & ns & ns \\
\hline \multicolumn{9}{|c|}{ 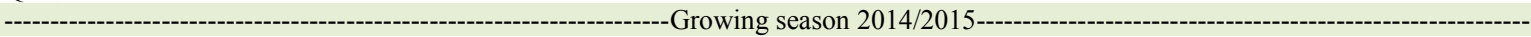 } \\
\hline 0 & 146 & 494 & 883 & 74 & 57 & 6.92 & 12.3 & 13.1 \\
\hline 40 & 121 & 412 & 945 & 77 & 60 & 5.48 & 12.3 & 13.1 \\
\hline 80 & 122 & 365 & 1098 & 84 & 61 & 4.52 & 14.1 & 14.8 \\
\hline 120 & 120 & 391 & 914 & 85 & 60 & 4.88 & 11.6 & 12.3 \\
\hline 160 & 131 & 374 & 952 & 89 & 61 & 4.40 & 11.0 & 11.8 \\
\hline Linear & ns & & ns & ns & ns & & ns & $\mathrm{ns}$ \\
\hline Quadratic & $\mathrm{ns}$ & ns & $\mathrm{ns}$ & ns & ns & ns & ns & ns \\
\hline
\end{tabular}

$\mathrm{ns},{ }^{*},{ }^{* *}$, not significant: effect of $\mathrm{P}$ rate not significant or significant at 5 and $1 \%$ probability levels, respectively. 
$\mathrm{Ca}$, which sometimes affect fruit quality, were not modified by treatments regardless of growing season (Table 3). AMARANTE et al. (2011) reported that the skin of 'Fuji' apples with N/Ca ration lower than 4.0 , with a flesh $\mathrm{K} / \mathrm{Ca}$ ratio lower than 37 , and with a skin $(\mathrm{K}+\mathrm{Mg}) / \mathrm{Ca}$ ratio lower than 40 had low incidence of bitter pit, one of the most important $\mathrm{Ca}$ related disorder.

The small effect of long-term $P$ addition to the soil on traits related to fruit quality can be partially explained by root association with mycorrhizae, which increase $\mathrm{P}$ absorption (GASTOL et al., 2016), in addition to the release of $\mathrm{P}$ from the soil organic matter decay, besides the small requirement of $\mathrm{P}$ by this specie.

\section{CONCLUSION}

The quality of 'Fuji Suprema' fruits was slightly affected by long-term annual additions of $\mathrm{P}$ to the soil. In addition, fruit quality and conservation remained in the adequate range. On some growing seasons; however, addition of $\mathrm{P}$ to the soil increased flesh firmness and decreased the skin red color.

\section{DECLARATION OF CONFLICTING INTERESTS}

The authors declared no potential conflicts of interest with respect to the research, authorship, and/or publication of this article.

\section{REFERENCES}

AMARANTE, C. V. T. et al. Composição mineral e severidade de "bitter pit" em maçãs 'Catarina'. Revista Brasileira de Fruticultura, v.28, p.51-54, 2006. Available from: <http:// www.scielo.br/scielo.php?script $=$ sci_arttext\&pid $=\mathrm{S} 0100$ 29452006000100016\&lng=pt\&tlng=pt $>$. Accessed: Dec. 3, 2012. doi:10.1590/S0100-29452006000100016.

AMARANTE, C. V. T. et al. Radiação, fotossíntese, rendimento e qualidade de frutos em macieira 'Royal Gala' cobertas com telas antigranizo. Pesquisa Agropecuária Brasileira, Brasília, v.42, p.925-931.2007. Available from: <http:// www.scielo.br/scielo.php? script $=$ sci arttext\&pid $=\mathrm{S} 0100$ 204X2007000700003>. Accessed: Dec. 10, 2012. doi:10.1590/ S0100-204X2007000700003.

AMARANTE, C. V. T. et al. O teor de cálcio na casca é indicativo da suscetibilidade ao "bitter pit" em maçãs 'Fuji'. Revista Brasileira de Fruticultura, v.33, p.180-186. 2011. Available from: <http:// www.scielo.br/pdf/rbf/v33n1/aop00211.pdf > . Accessed: Oct. 12, 2012. doi:10.1590/S0100-29452011005000017.

AMARANTE, C. V. T. et al. Composição mineral de maçãs 'Gala' e 'Fuji' produzidas no Sul do Brasil. Pesquisa Agropecuária Brasileira, v.47, p.550-560. 2012. Available from: $\quad<$ http://www.scielo.br/scielo.php?pid=S0100-
204X2012000400011\&script=sci_abstract $>$. Accessed: Mar. 23, 2013. doi:10.1590/S0100-204X2012000400011.

ARGENTA, L. C. et al. Padrões de maturação e índices de colheita de maçãs cvs. Gala, Golden Delicious e Fuji. Pesquisa agropecuária Brasileira, v.30, p.1259-1266. 1995. Available from: $\quad<$ https://seer.sct.embrapa.br/index.php/pab/article/ view/4423/1709>. Accessed: Set. 9, 2014.

BRACKMANN, A. et al. Aplicações pré-colheita de cálcio na qualidade pós-colheita de maçãs 'Fuji'. Ciência Rural, v.40, p.1435-1438. 2010. Available from: <http://www.scielo.br/pdf/cr/ v40n6/a616cr2318.pdf>. Accessed: Set. 11, 2012. doi:10.1590/ S0103-84782010000600032.

COMISSÃO DE QUÍMICA E FERTILIDADE DO SOLO CQFS-RS/SC. Manual de calagem e adubação para os Estados do Rio Grande do Sul e de Santa Catarina. Sociedade Brasileira de Ciência do Solo - Núcleo Regional Sul. 10 Ed: 376. 2016.

ERNANI, P. R. et al. Decréscimo da retenção de fósforo em função do aumento do pH. Revista Brasileira de Ciência do Solo, v.20, p.159-162. 1996.

GĄSTOL, M. et al. The effect of mycorrhizal inoculation and phosphorus application on the growth and mineral nutrient status of apple seedlings. Journal of Plant Nutrition, v.39, p.288-299. 2016. doi:10.1080/01904167.2015.1109114.

HUNSCHE, M. et al. Efeito da adubação potássica na qualidade pós-colheita de maçãs “Fuji ”. Pesquisa Agropecuária Brasileira, v.38, p.489-496. 2003. Available from: <http://www.scielo.br/pdf/ pab/v38n4/a07v38n4.pdf>. Accessed: Oct. 28, 2012. doi:10.1590/ S0100-204X2003000400007.

JOHNSON, D. S.; YOGORATNAM, N. The effects of phosphorus sprays on the mineral composition and storage quality of Cox's Orange Pippin apples. Journal of Horticultural Science, v.53, p.171-178. 1978. doi:10.1080/00221589.1978.11514815.

NAVA, G. et al. 'Fuji' apple tree response to phosphorus fertilization. Revista Brasileira de Fruticultura, 39, (e-369). 2017. Available from: $<\mathrm{http}$ //www.scielo.br/scielo.php?script=sci arttext\&pid $=$ S0100-29452017000103001 $>$. Accessed: Set. 28, 2017. doi:10.1590/0100-29452017369.

NEILSEN, G. H. et al. Annual Bloom-time phosphorus fertigation affects soil phosphorus, apple tree phosphorus nutrition, yield, and fruit quality. HortScience, v.43, p.885-890. 2008. Available from: <http://hortsci.ashspublications.org/content/43/3/885.full >. Accessed: Set. 10, 2016.

NEILSEN, D.; NEILSEN, G. Nutritional effects on fruit quality for apple trees. New York Fruit Quarterly, v.17, p.21-24. 2009. Available from: <https://fruit.triforce.cals.wisc.edu/wp-content/ uploads/sites/36/2016/03/Nutrition-effects-fruit-quality.pdf $>$. Accessed: Jan. 23, 2016.

SCHMITT, D. E. et al. Phosphorus fractions in apple orchards in southern Brazil. Bragantia, v.76(3), p.422-432. 2017. Available from: $\quad<$ http://www.scielo.br/scielo.php?script=sci_arttext\&p id=S0006-87052017000300422>. Accessed: Nov. 20, 2017. doi:10.1590/1678-4499.173.

SOUZA, F. et al. Qualidade de maçãs 'Fuji' influenciada pela adubação nitrogenada e potássica em dois tipos de solo. Revista 
Brasileira de Fruticultura, v.35, p.305-315. 2013. Available from: $<$ http://www.scielo.br/scielo.php?script=sci_arttext\&pid=S010029452013000100035\&lng=en\&nrm=iso\&tlng=pt $>$. Accessed: Nov. 20, 2015. doi:10.1590/S0100-29452013000100035.

TEDESCO, M. J. et al. Análise de solo, plantas e outros materiais. Universidade Federal do Rio Grande do Sul. (Boletim Técnico, 5). 1995.

TREPTOW, R. O. et al. Caracteriazção físico-química e sensorial de quatro cultivares de maçãs (Malus doméstica Borkh.). Revista Brasileira de Agrociência, v.1, p.179-184. 1995. Available from: $<$ https://periodicos.ufpel.edu.br/ojs2/index.php/CAST/article/ view/141/138>. Accessed: Nov. 20, 2015. doi:10.18539/cast. v1i3.141.

WEBSTER, D. H.; LIDSTER, P. D. Effects of phosphate sprays on McIntosh apple fruit and leaf composition, flesh firmness and susceptibility to low-temperature disorders. Canadian Journal of Plant Science, v.66, p.617-626. 1986. doi:10.4141/cjps86082 .

WOJCIK, P.; WOJCIK, M. Response of mature phosphorusdeficient apple trees to phosphorus fertilization and liming. Journal of Plant Nutrition, v.30, p.1623-1637. 2007. doi:10.1080/01904160701615509. 